\title{
From spring sources to springbrook: Changes in environmental characteristics and benthic fauna
}

\author{
Elżbieta Dumnicka ${ }^{1}$, Joanna Galas ${ }^{1}$, Igor Jatulewicz ${ }^{2}$, Joanna Karlikowska ${ }^{2} \&$ \\ Bartłomiej RzONCA ${ }^{3}$ \\ ${ }^{1}$ Institute of Nature Conservation, Polish Academy of Sciences, al. A. Mickiewicza 33, 31-120 Kraków, Poland; e-mail: \\ dumnicka@iop.krakow.pl \\ ${ }^{2}$ Jan Dtugosz University of Częstochowa, Institute of Chemistry, Environmental Protection and Biotechnology, al. Armii \\ Krajowej 13/15, 42-200 Częstochowa, Poland \\ ${ }^{3}$ Jagiellonian University, Institute of Geography and Spatial Management, Gronostajowa 7, 30-387 Kraków, Poland
}

\begin{abstract}
Spatial patterns in macroinvertebrate communities and some abiotic factors were examined in three rheocrene springs and their springbrooks (Kraków-Częstochowa Upland, southern Poland). The mean discharge of particular springs ranged from 5 to $11 \mathrm{~L} \mathrm{~s}^{-1}$, and its annual fluctuations were small. Water temperature was very stable at all sampling sites. In the eucrenon the number of benthic taxa was the smallest (9-14 determined to the family level), but the densities were the highest (approx. 14000 ind. $\mathrm{m}^{-2}$ ). The biggest changes in macroinvertebrate composition were observed in the modified hypocrenon, which is an artificial pond. The lowest number of taxa were found in a natural, short springbrook with a nondiversified bottom substrate. The density of crenophilic taxa (Drusus trifidus, Dugesia gonocephala, Elmidae) diminished along the springbrooks, while the opposite trend was observed for ubiquitous taxa (some Oligochaeta, Asellus aquaticus and Chironomidae). Even in a very short natural springbrook $(30 \mathrm{~m})$, Drusus trifidus, the only species of Trichoptera found in the springs discussed here, goes through the entire development cycle. The strongest influence of a big river was observed at the outflow of one of the natural springbrooks, where the highest number of riverine oligochaete species were found. The benthic fauna of the springs studied here differed from that found in other springs in this area - the absence of the typical crenophilic species Bithynella austriaca (Gastropoda) and the presence of Gianus aquedulcis (Oligochaeta) may indicate the autonomy of the spring fauna in the Mstów area, possibly resulting from the postglacial geomorphological formation of this region or differences in habitat conditions.
\end{abstract}

Key words: abiotic parameters; benthic fauna; Kraków-Częstochowa Upland

\section{Introduction}

Freshwater springs, as aquatic habitats, are known for their unique properties, such as relatively stable physical and chemical conditions (Glazier 1991; Goch \& Glazier 1991; Van der Kamp 1995). Owing to their stenothermy, organisms living there (crenobionts and crenophiles) are well adapted to such conditions (Botosaneanu 1998; Cantonati et al. 2006). As the distance from the spring increases, physico-chemical parameters of the water rapidly change, affecting the composition and structure of the benthic community (Smith et al. 2003; Von Fumetti et al. 2007; Barquin \& Death 2011). A stable discharge is exceptionally rare; in most cases seasonal fluctuations are observed. Discharge changes may influence the deposition or washing out of benthic organic matter (Fischer \& Likens 1973), which in turn may cause differences in community composition (Mc Cabe 1998). Generally, in springs with a higher discharge, benthic fauna is more diverse, as it includes species not found in springs characterized by a small discharge (Lindegaard et al. 1998).
An earlier investigation of 25 springs situated in the Kraków-Częstochowa Upland (southern Poland) showed that, although similar in their physico-chemical parameters, they differed more considerably in the mean discharge value, substratum type and sediment organic matter content (Galas 2005), which strongly affected the taxonomic richness of their benthic fauna (Dumnicka et al. 2007; Koperski et al. 2011).

Most of the springs in the Kraków-Częstochowa Upland are of the rheocrene and rheo-limnocrene type (Dynowska 1983; Chełmicki 2001), and until now biological studies have been performed in spring niches only (Czachorowski 1990; Biesiadka et al. 1990; Dumnicka, 2006; Koperski et al. 2011). Generally, few studies have compared benthic communities in springs (eucrenon) with those in springbrooks (hypocrenon) (McCabe \& Sykora 2000; Smith 2002; Barquin \& Death 2004, 2011). The above studies were conducted along a distance of up to $1 \mathrm{~km}$ downstream from the spring under various climatic conditions, whereas Resh (1983) and Von Fumetti et al. (2007) investigated very short natural springbrooks. Data from the 1950s to the 1990s 
on the physical changes along the course of springbrooks and on the responses of benthic macroinvertebrate communities to these changes were gathered by Mc Cabe (1998). He discussed a complex of abiotic factors determining the distribution of macroinvertebrates in springs and natural springbrooks.

The abiotic parameters of the three springs studied here were similar, whereas the springbrooks differed in both the length and bottom character. Two springbrooks were natural, and the third formed an encased pond. The main aim of this study was to test the hypothesis that the composition of the benthic community (with special regard to Oligochaeta taxa) and the density of specific taxa depend on the character of the springbrook, especially its bottom substrate. Moreover, the effect exerted on the benthic fauna by a big river
(Warta River) into which the springbrooks flow was also studied.

\section{Material and methods}

The three karstic springs and their springbrooks are located on the edge of the Kraków-Częstochowa Upland and flow into the Warta River near the village of Mstów (Fig. 1). They drain strongly karstified Oxford and Rauracian limnestones and marls (Dynowska 1983), covered by sands and boulder clay (Chełmicki 2001). All three springs are rheocrenic and belong to a hillside, fissure and descending type. The area of the spring niche is small - approximately $1 \mathrm{~m}^{2}$. The springs and springbrooks 1 and 2 have a natural character; their location, hydrology and water chemistry have already been shortly described (Dynowska 1983; Chełmicki 2001). The bottom is mostly stony in all three springs but

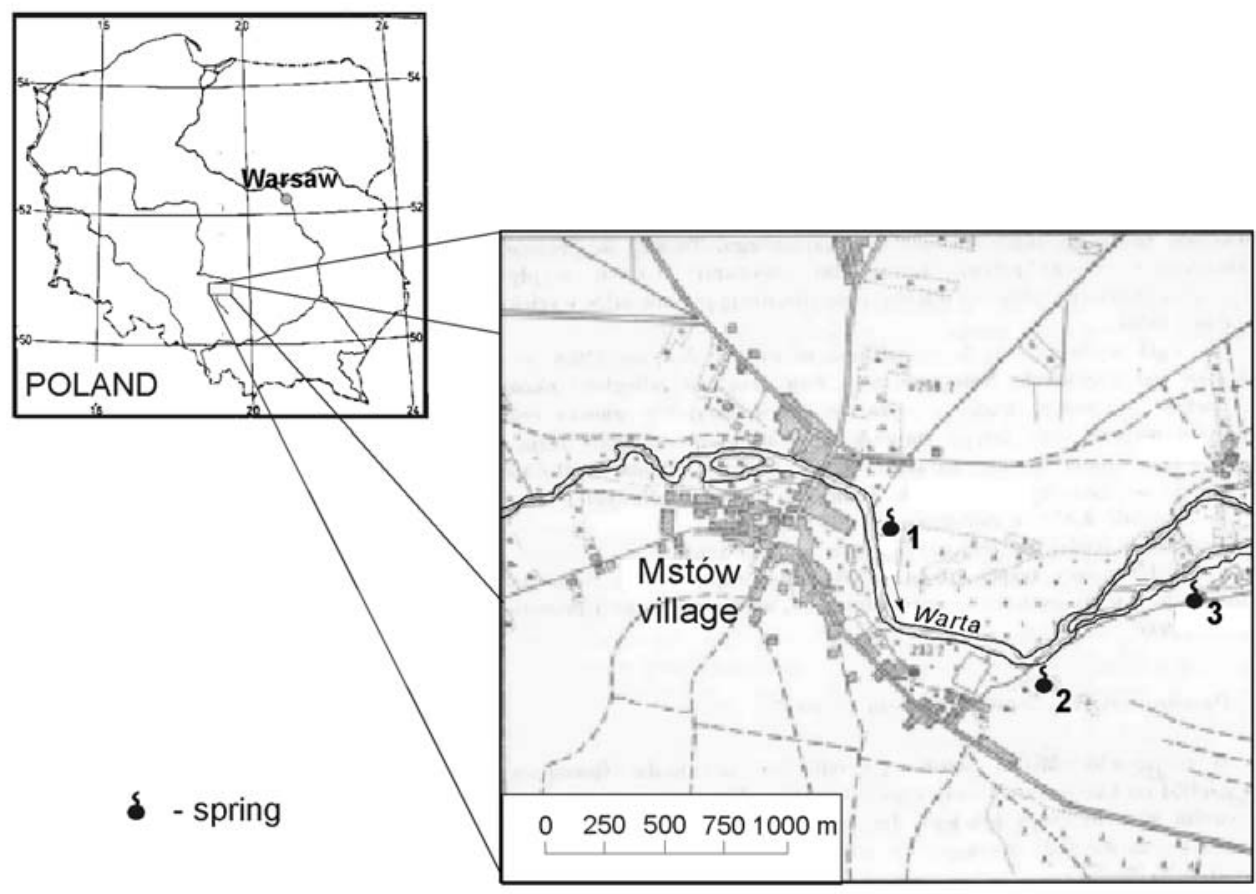

Fig 1. Sampling area with the location of the studied springs.

Table 1. Characteristics of the sampling sites.

\begin{tabular}{|c|c|c|c|c|}
\hline Sampling site name & Code & Substrate composition (\%) & $\begin{array}{c}\text { Distance from } \\
\text { spring source }(\mathrm{m})\end{array}$ & $\begin{array}{l}\text { Discharge } \\
\left(\mathrm{L} \mathrm{s}^{-1}\right)\end{array}$ \\
\hline Spring 1 & $(\mathrm{~S} 1)$ & pebbles, small stones (95), vegetation (5) & 0 & $5^{*}, 5^{* *}$ \\
\hline \multicolumn{5}{|c|}{ (1 } \\
\hline middle part 1 & (M1) & pebbles (95), vegetation (5) & 15 & \\
\hline outflow to river 1 & (O1) & sand (90), pebbles (5), vegetation (5) & 30 & \\
\hline Spring 2 & $(\mathrm{~S} 2)$ & pebbles, small stones $(80)$, sand $(20)$ & 0 & $40^{*}, 16.8^{* *}, 10.7$ \\
\hline \multicolumn{5}{|l|}{ Springbrook: } \\
\hline outflow to river 2 & $(\mathrm{O} 2)$ & pebbles, small stones (70), sand (25), vegetation (5) & 50 & \\
\hline Spring 3 & $(\mathrm{~S} 3)$ & small stones $(90)$, sand $(10)$ & 0 & 8 \\
\hline \multicolumn{5}{|l|}{ Springbrook (pond): } \\
\hline middle part 3 & (M3) & sand (95), vegetation, detritus (5) & $3-4$ & \\
\hline outflow to river 3 & (O3) & sand $(75)$, detritus, mud (20), vegetation (5) & $9-10$ & \\
\hline Warta River & & sand $(90)$, mud $(10)$ & & $25.400 .000^{* * *}$ \\
\hline
\end{tabular}

Explanations: * Dynowska (1983), ** Chełmicki (2001), *** mean discharge of Warta River, calculated for 30 years at Działoszyn town (below Mstów village). 
more diversified in the very short springbrooks (Table 1). Spring 3 flows into a small pond, constructed 50 years ago, but its earth banks are still preserved along with two outflows by weirs: one to the Warta River, the other to another pond (Dumnicka 2009). Patches of Phragmites australis prevailed near the banks of springbrook 1 and the Warta River, whereas other emergent plants were found in the other two springbrooks (Berula erecta, Sparganium ramosum, Mentha aquatica). Moreover, Veronica beccabunga was found in springbrook 2 .

Samples of benthic macroinvertebrates, water and sediment were collected from the springs: S1, S2 and S3, the middle parts of the springbrooks: M1, M2, M3 and from the springbrook outflows to the Warta River: O1, O2, O3. One site in the Warta River between springbrooks 1 and 2 was also sampled. Sites S1, M1, O1 were sampled in June, July, September and October 2008; S2, M2, O2, S3, M3, O3 were sampled in April, July and November 2007 as well as February 2008, the Warta River only in February and June 2008. Additionally, in S2, discharge, conductivity and oxygen saturation were measured every month from 2007 to 2008 starting in January. Data from the physical and chemical analyses of water (maximum, minimum and average values in the Warta River for January - December 2008 were obtained from the Voivodeship Inspectorates of Environmental Protection in Katowice (VIEP).

Temperature, $\mathrm{pH}$ and conductivity were measured in situ with a portable probe (Elmetron $\mathrm{pH}$-meter CX742). Water samples for oxygen analysis were taken into glass bottles and analysed in a laboratory by the Winkler method. The nitrate content was analyzed in a laboratory by ion chromatography IC DX - 320 with an analytic column AS15 $4 \mathrm{~mm}$ (DIONEX). Monthly discharge for 2007-2008 was measured by the float method (http://www.usbr.gov/pmts/hydraulics_lab/pubs/wmm/ chap13_10.html).

The mean value of precipitation for 2007-2008 was obtained from the Institute of Meteorology and Water Management.

Macroinvertebrates (two samples per site) were collected from fine sediments with a plastic corer $(4 \mathrm{~cm}$ in diameter), which was driven into the substratum to a depth of $5 \mathrm{~cm}$. One sample was also taken from the coarse substratum with a bottom scraper $(15 \times 15 \mathrm{~cm}$ frame with a $0.2 \mathrm{~mm}$ mesh). Benthic invertebrates from all samples were sorted under a stereo-microscope and preserved in $4 \%$ formaldehyde. Oligochaeta, Amphipoda, Isopoda, Plecoptera, Trichoptera, Ephemeroptera and Gastropoda were identified to the species level, and almost all other taxonomic groups were identified to the family level. Fauna densities were calculated separately for fine and coarse sediments, and the mean value for the two types of substrates was used for further procedure.

The fine sediment samples remaining after invertebrates had been removed were dried to a constant weight at $105^{\circ} \mathrm{C}$ and weighed. The organic matter content was determined after igniting the sediment at $550{ }^{\circ} \mathrm{C}$ for $2 \mathrm{~h}$. The results were expressed as the percentage of organic matter. Altogether, 96 fauna samples, 53 sediment samples and 59 water samples were collected during the study period.

\section{Statistics}

The distribution of variables such as precipitation, discharge, oxygen saturation and conductivity did not significantly differ from the normal one $(P>0.05$, Shapiro-Wilk test), and Pearson correlations for discharge vs. the other parameters were calculated.
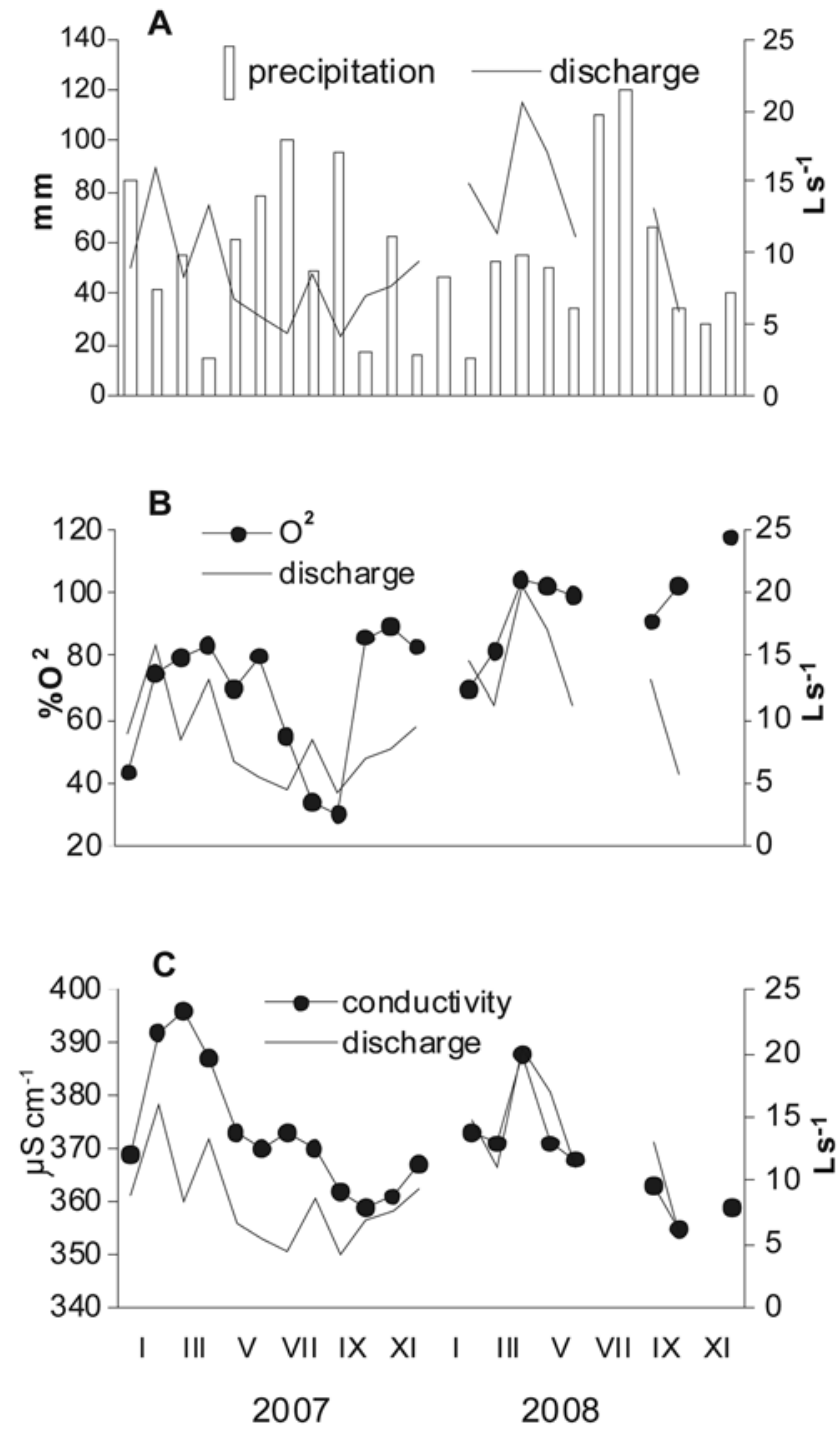

Fig. 2. Annual values (min, max and SD) of: A - water temperature, $\mathrm{B}$ - nitrates, $\mathrm{C}$ - organic matter in sediments.

Because the number of benthic fauna samples collected from each site was small, the annual mean was used for further calculations. The variability of the densities of the prevailing taxa between sampling sites: S, M and $\mathrm{O}$ were calculated with a non-parametric Kruskal-Wallis test. All calculations were performed with STATISTICA 5.0.

\section{Results}

\section{Water and sediments}

Over the two-year study period the mean monthly precipitation value varied from 14 to $100 \mathrm{~mm}$ (Fig. 2A). Small differences in the amount of precipitation between hydrological years 2007 and 2008 were observed. Over the same time, the discharge measured monthly in $\mathrm{S} 2$ changed from $4.1 \mathrm{~L} \mathrm{~s}^{-1}$ in September 2007 to $20.4 \mathrm{~L} \mathrm{~s}^{-1}$ in March 2008 (the mean value was $8.3 \mathrm{~L}^{-1}$ in 2007 and $12.9 \mathrm{~L} \mathrm{~s}^{-1}$ in 2008). The maximal value of spring discharge was measured a few months after the maximal precipitation. 

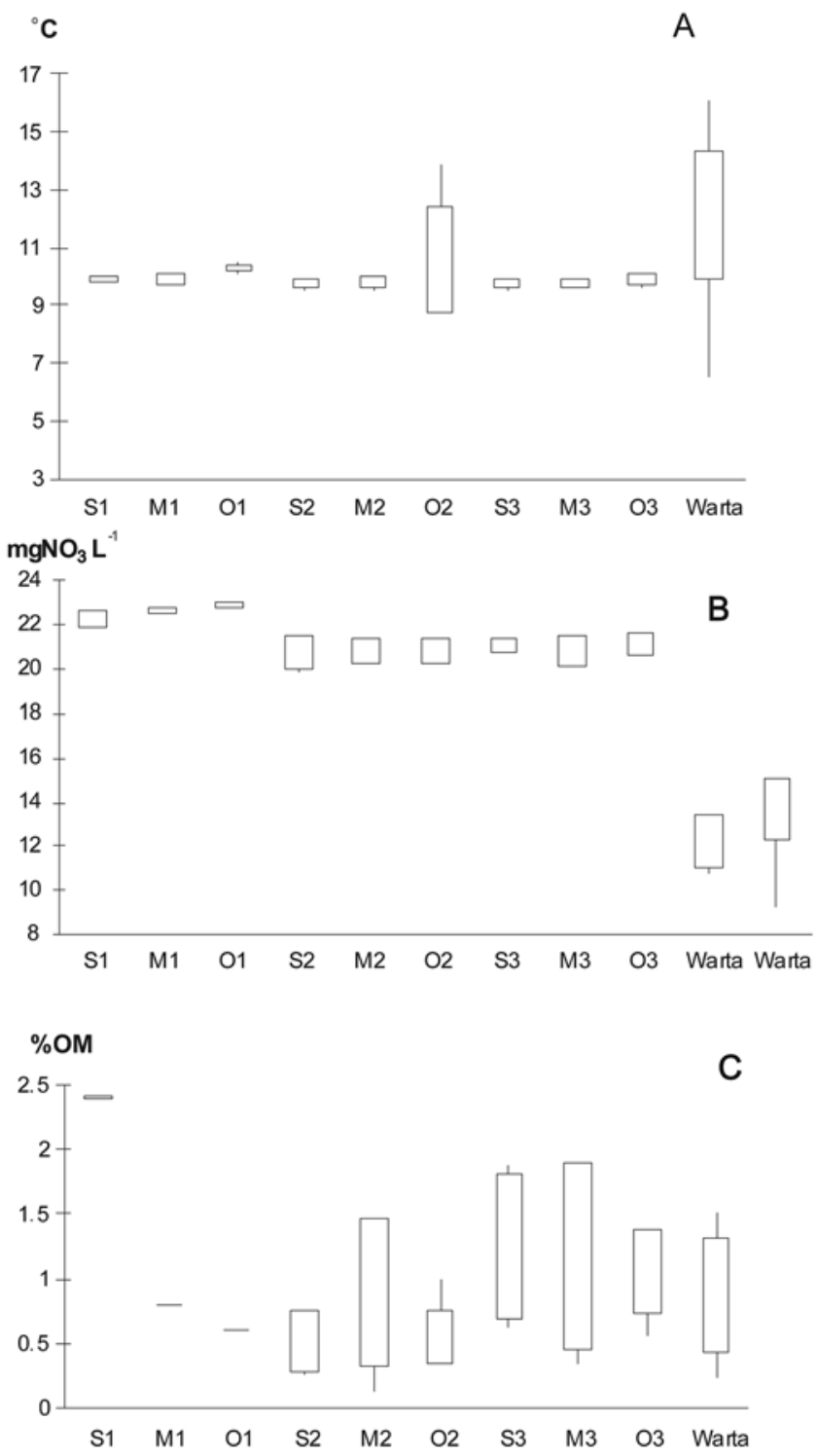

Fig. 3. Mean monthly values of: A - precipitation, B - conductivity, $\mathrm{C}$ - oxygen saturation compared with discharge changes.

During seasonal studies, water oxygen saturation levels varied from 46 to $102 \% \mathrm{O}_{2}$, and were similar regardless of the place of sampling: $\mathrm{S}, \mathrm{O}$ and $\mathrm{M}$, while over the two-year study period these changes fluctuated more widely (Fig. 2B) and were weakly positively correlated with discharge values $(r=0.43, P=0.056)$.

Temperature at all sampling sites (except for the sampling site in the Warta River) was very stable, even at M3 and O3, which were situated within the pond (Fig. 3A). The mean temperature was $9.9^{\circ} \mathrm{C}$, ranging from 9.3 to $10.1^{\circ} \mathrm{C}$, except for site $\mathrm{O} 2\left(9.5-13.9^{\circ} \mathrm{C}\right.$, mean $10.6 \mathrm{C})$, which is flat, shallow and temporarily flooded by the Warta River. All sites had slightly alkaline waters with the mean $\mathrm{pH}$ value ranging from 7.34 to 7.8 . The concentrations of $\mathrm{NO}_{3}$ at all sites were high, with the highest values for S1, M1 and $\mathrm{O} 1\left(22.6 \mathrm{mg} \mathrm{L}^{-1}\right)$ (Fig. 3B). At the sampling point in the Warta River the content of nitrates was much lower - only $12.2 \mathrm{mg} \mathrm{L}^{-1}$ during seasonal studies. A somewhat wider annual am-

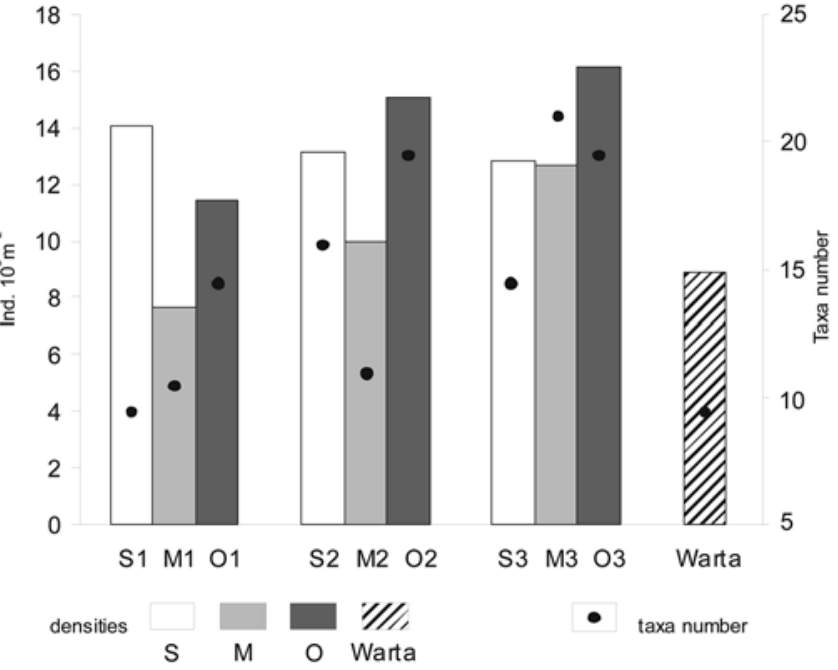

Fig. 4. Mean macroinvertebrate densities and the number of taxa found at the sampling sites.

plitude was found during monthly studies performed by VIEP (Fig. 3B). At all sites, the organic matter content was fairly low, with a mean value of $0.9 \% \mathrm{OM}$ (0.3-2.4\%), although the results for sites S1, M1 and O1 come from one sampling period only (Fig. 3C). At the sampling point in the Warta River the results were similar.

\section{Fauna}

Twenty-six families and three higher taxa (Nematoda, Ostracoda and Hydracarina) were found in the three eucrenon and hypocrenon zones, but only ten families were found in the Warta River. Some families were represented by single species. These included dominant species collected at all sampling sites: Gammarus fossarum, Drusus trifidus and Dugesia gonocephala, as well as species represented by only a few specimens at one or two sampling sites: Baetis alpinus (Ephemeroptera), Nemurella picteti, Nemoura cinerea (Plecoptera), Niphargus tatrensis (Amphipoda) and Ancylus fluviatilis (Gastropoda).

The number of taxa found in the springs varied from 9 to 14, while in the springbrooks greater variability was observed (Fig. 4). The densities of benthic fauna in the three springs were similar, but in the other zones they differed distinctly, and the lowest values were noted in the middle parts of the two natural springbrooks. In the modified springbrook, the density was almost the same at M3 and S3. In the Warta River the fauna density was lower compared with the other sites.

Typically crenophilic taxa: Drusus trifidus, coleopteran larvae from the family Elmidae and Dugesia gonocephala were found at all sites, with the highest densities noted in the springs (Fig. 5). A statistically significant decrease in the density was found for D. trifidus at all sites below springs, whereas for the other taxa only at M2 and M3 (Fig. 5). Several taxa, such as Asellus aquaticus, Ostracoda and Hydracarina, were absent at S1, M1, O1, but they were the most numer- 

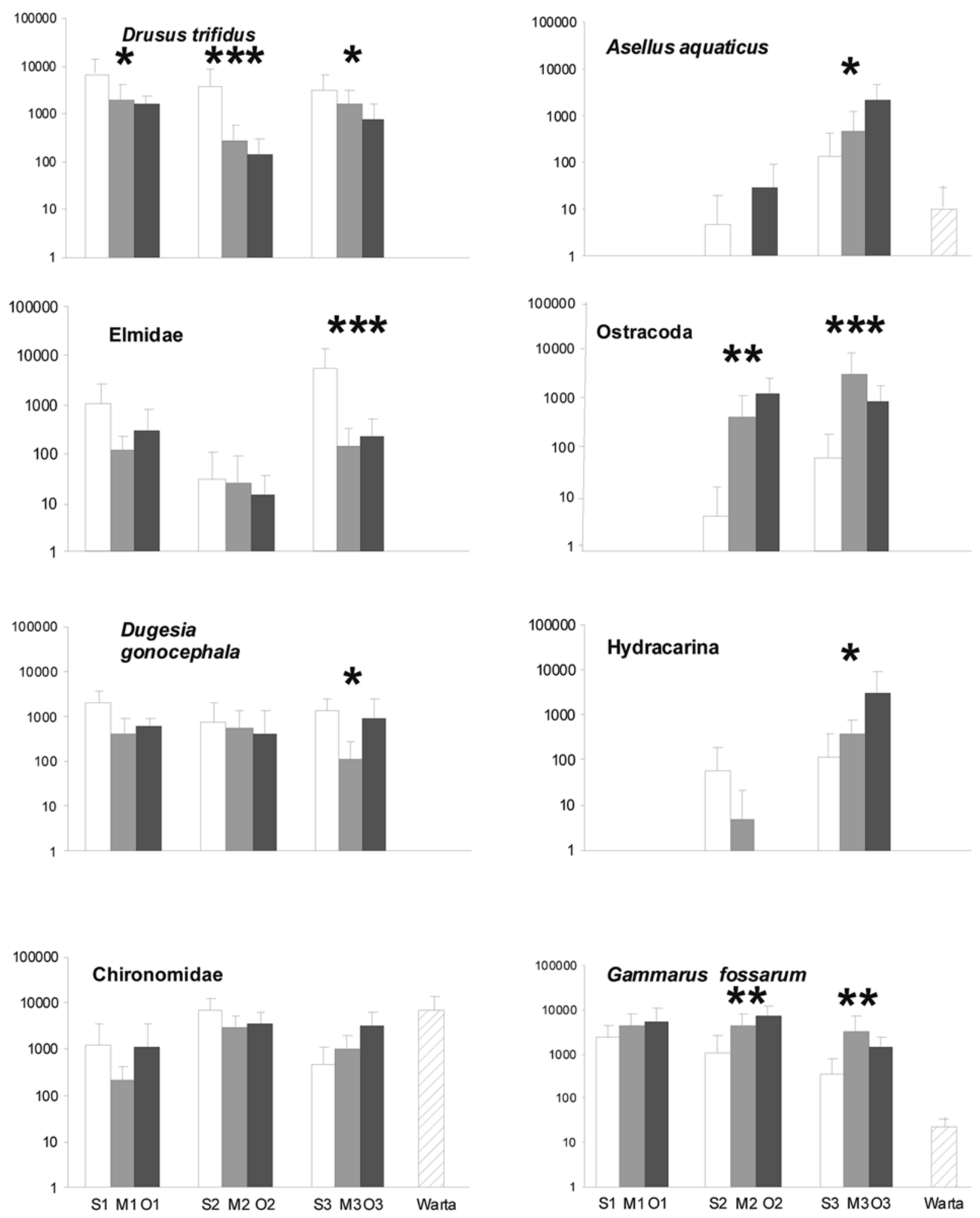

Fig. 5. Longitudinal changes of in the densities of selected invertebrate taxa; ${ }^{*} P<0.05-0.01,{ }^{* *} P<0.01-0.001,{ }^{* * *} P<0.001$.

ous at S3, M3, O3. Their densities usually increased from $\mathrm{S}$ to $\mathrm{O}$, and differences in the densities were statistically significant (Fig. 5), especially at S3, M3, O3. Similar density changes were observed for Gammarus fossarum. Most of the above mentioned taxa were not found in the Warta River.

Changes in the density of the five larval stages of Drusus trifidus at S1, M1 and O1, where the samples were taken during the whole development season, are shown in Fig. 6. First-instar larvae were the most numerous in June and July at S1. Their densities were distinctly lower in the following months at site S1 and at all sampling times at the other two sites (M1, O1) (Fig. 6). The density of second-instar larvae increased from June (748 ind. $\mathrm{m}^{-2}$ ) to the maximum in September $\left(2684\right.$ ind. $\left.\mathrm{m}^{-2}\right)$ at $\mathrm{S} 1$. At M1 the most abundant 

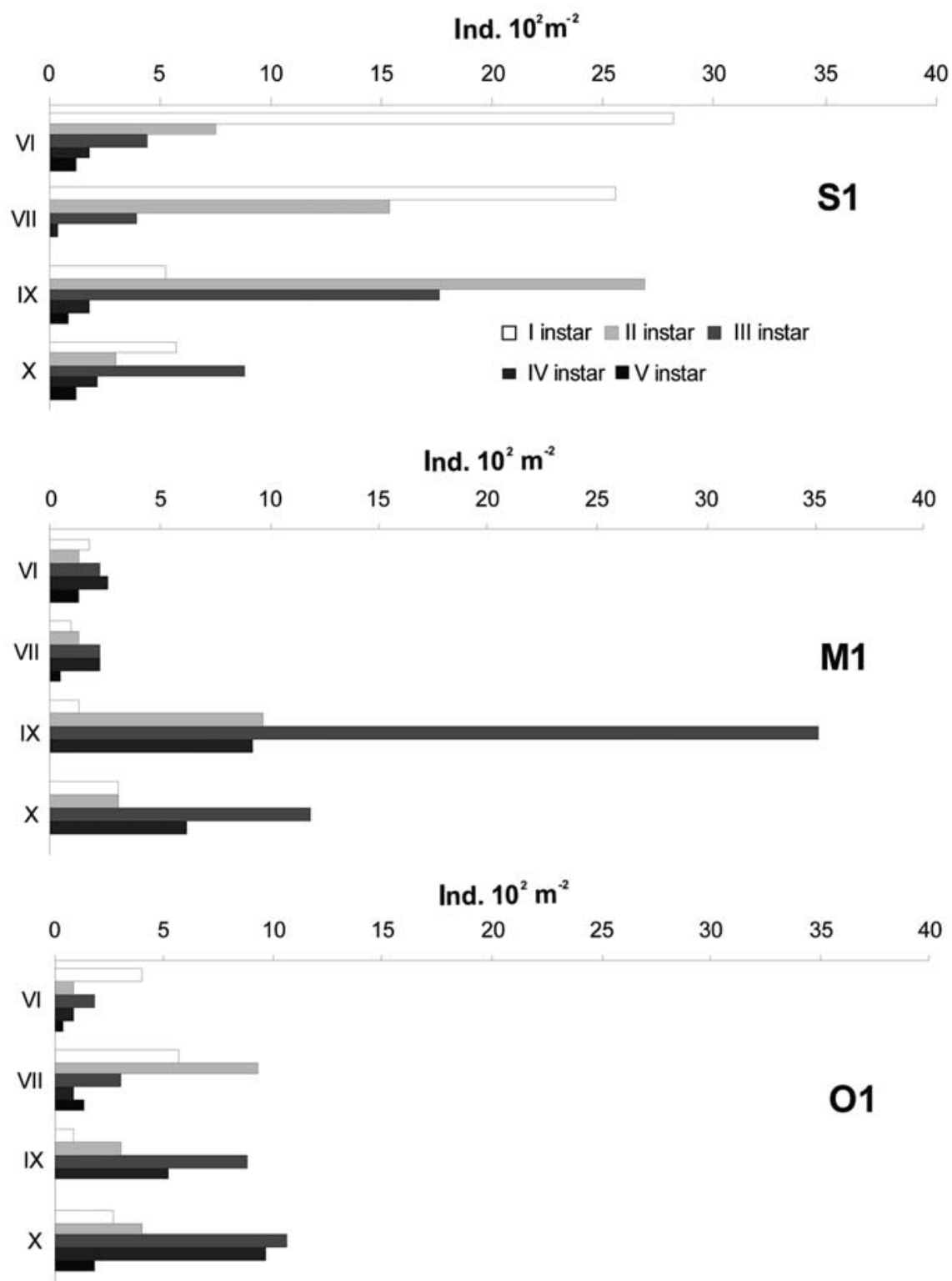

Fig. 6. Density of the larval stages of Drusus trifidus at the S1, M1 and O1 sites during the study period.

stage was the second instar in September (3540 ind. $\mathrm{m}^{-2}$ ), whereas at the outflow to the river the density of larvae in all stages of development was low, and in September and October third- and fourth-instar larvae prevailed (Fig. 6).

Oligochaetes were found at all sampling points, but they were the most numerous in the Warta River (Table 2). The smallest number of oligochaetae taxa were present in spring S1 and in its springbrook, whereas the greatest number of species were found at O2. The influence of the Warta River on species composition could be seen in springbrooks, where such typically riverine species as Aulodrilus pluriseta, Tubifex ignotus and T. tubifex were noted (Table 2). Nais elinguis, a ubiquitous species, was able to survive even at S2. Rhyacodrilus falciformis, characteristic of karstic waters, was found at S3, M3 and O3 exclusively.

The most characteristic oligochaete species observed in springs situated in the Mstów area was Gianius aquedulcis, a species typical of interstitial waters.
Moreover, at S2 two other subterranean aquatic taxa were found: Cernosvitovilla parviseta and Trichodrilus sp. juv.

Although in principle only benthic fauna was studied here, some semi-aquatic or soil species were also found (Marionina argentea, Mesenchytraeus armatus, Henlea nasuta, Cognettia sphagnetorum).

\section{Discussion}

All springs were permanent, fed from the same deep water-yielding stratum. The discharge of S2 has diminished distinctly since the 1970s, probably because of a change in hydrological conditions (a road has been built just above S2), whereas the discharge of the natural spring at S1 did not change (Dynowska 1983; Chełmicki 2001). The changeability index (Pazdro \& Kozerski 1990) for S2 calculated for 2007 and 2008 was 3.9 and 3.5 , respectively, which means that the discharge was relatively stable during these two years. This was re- 
Table 2. Species/taxa of Oligochaeta (ind. $\mathrm{m}^{-2}$ ) found at all sites.

\begin{tabular}{|c|c|c|c|c|c|c|c|c|c|c|}
\hline Stylodrilus heringianus Claparède, 1862 & 216 & & & & & 83 & & & 6 & \\
\hline Nais bretscheri Michaelsen, 1899 & 6 & & 11 & & & & & & 11 & \\
\hline Gianius aquedulcis (Hrabě,1960) & & 210 & 995 & 110 & 166 & 381 & 398 & 420 & 1619 & \\
\hline Nais elinguis O.F. Müller, 1774 & & 50 & 28 & 413 & 724 & 557 & & & 72 & 15 \\
\hline Nais communis O.F. Müller, 1774 & & 6 & & 11 & & 17 & & & 11 & \\
\hline Cernosvitoviella parviseta Gadzińska, 1974 & & & & 50 & & & & & & \\
\hline Trichodrilus sp. juv. & & & & 6 & & & & & & \\
\hline Henlea nasuta (Eisen, 1878) & & & & 6 & & & & & & \\
\hline Nais variabilis Piguet, 1906 & & & & 11 & & 28 & 11 & & 105 & \\
\hline Cognettia sphagnetorum Vejdovský, 1877 & & & & 50 & & 23 & 44 & & & \\
\hline Cernosvitoviella atrata (Bretscher, 1903) & & & & & 50 & 6 & & 6 & 6 & \\
\hline Chaetogaster diaphanus (Gruithuisen, 1828) & & & & & & 17 & & & & 11 \\
\hline Limnodrilus udekemianus Claparède, 1862 & & & & & & 6 & & & & 408 \\
\hline Mesenchytraeus armatus (Levinsen, 1884) & & & & & & 6 & & & & \\
\hline Eiseniallea tetraedra (Savigny, 1826) & & & & & & 6 & & & & \\
\hline Propappus volki Michaelsen, 1916 & & & & & & 11 & & & & 11 \\
\hline Rhyacodrilus falciformis Bretscher, 1901 & & & & & & & 50 & 6 & 50 & \\
\hline
\end{tabular}

Explanations: For sampling site codes see Table 1.

flected in the chemical parameters of waters and the stability of the bottom substrate.

A relatively high mean water temperatures confirmed deep alimentation of these springs. Erman \& Erman (1995) defined the boundary of the eucrenon (spring) as the point where water temperature differs from that in its springbrook by $2^{\circ} \mathrm{C}$, but temperature in the springs and springbrooks studied here was almost the same. Despite the absence of a thermal gradient in the short springbrooks, the composition and density of benthic fauna changed significantly, which indicates that temperature is not the only determinant of the above parameters in the case of macroinvertebrates. A higher temperature noted in $\mathrm{O} 2$ reflected the influence of the Warta River waters via hyporheos or surface flooding - even with slight water level increases in the river. The presence of riverine oligochaete species at sites M2 and $\mathrm{O} 2$ also speaks for the contact between the springbrook and river waters.

The concentration of nitrates in all springs and springbrooks studied here was very high, significantly higher than that found in other springs previously studied in this region (Galas 2005; Chełmicki 2001) as well as in the Warta River. However, this parameter had no influence on the diversity of benthic fauna, which was comparable with results obtained for springs with low nitrate concentrations (Dumnicka et al. 2009) and significantly higher than in the river. The populations of invertebrate species characteristic of clean waters, not only crenophilic ones, were not detected in the Warta River. The sandy riverine habitat was also less favorable for crustaceans (Gammarus fossarum and Asellus aquaticus), so their densities were distinctly lower in the Warta River than in the springbrooks. Only Chi- ronomidae and Oligochaeta were more abundant in the river, but the diversity of the latter was low.

There are some studies comparing the benthic community structure in the longitudinal gradient from eucrenon to hypocrenon parts of running waters (Resh 1983; Barquin \& Death 2004, 2011; Von Fumetti et al. 2007). Their results show two possible patterns: the richness of species within the spring is lower than in the downstream areas (Meffe \& Marsh 1983; Barquin $\&$ Death 2004) or vice versa (Resh 1983). On the basis of the studies of many springs and their outflows, Von Fumetti et al. (2007) suggested that there is a possibility for both situations or even for the similarity of taxa richeness between the spring and the springbrook. The fewest taxa were found in the spring with the lowest discharge and the shortest springbrook with homogenous bottom substrate in M1 and O1. In the other two springs with a higher discharge, fauna diversity was also higher.

Barquin \& Death (2004) and Resh (1983) found that the densities of benthic fauna in springs were the highest, in contrast to its small diversity. Von Fumetti et al. (2007) observed similar trends, but sometimes with lower densities in the middle parts of the brooks, as in two springbrooks studied here. This may be the effect of smaller densities of taxa belonging to different ecological types: crenophilic and riverine. For particular taxa of these two types density changes observed along the springbrooks were statistically significant (Fig. 5). Similar density changes were also observed in the pond (M3 and O3), which is apparently a very favorable habitat for benthic fauna, since both the density and the number of taxa were the highest there. 
The contact of river waters with the springbrook modified fauna composition in the latter. This influence was very clear in $\mathrm{O} 2$, where the highest number of riverine species were observed. For example Nais elinguis, a species typical of moderately polluted waters (Uzunov et al. 1988), penetrated up to S2. Riverine species present in springbrooks do not appear to represent strong competition for spring fauna, as indicated by their joint occurrence.

A comparison of the benthic fauna in the three springs studied here with the fauna in ten springs in the northern part of the Kraków-Częstochowa Upland studied previously (Dumnicka et al. 2007; Koperski et al. 2011) reveals some considerable differences. In all springs studied in 2003 Bithynella austriaca was found, usually in large numbers (Koperski et al. 2011). This species was absent, however, in the Mstów springs, where Gastropoda were represented only by Ancylus fluvialitis. In the former spring studies Gianus aquedulcis (Oligochaeta) was not found, whereas in the three Mstów springs and springbrooks its density was high. This species is typical of interstitial waters and has rarely been observed in such habitats in Germany, France and Spain (Dumnicka 2009). The above mentioned differences in the composition of benthic macroinvertebrates may indicate the autonomy of the spring fauna in the Mstów area, which may be an effect of postglacial geomorphological formation of this region or differences in habitat conditions.

Studies on the caddisfly fauna of springs in this area usually showed the occurrence of a few taxa in most springs (Czachorowski 1990; Koperski et al. 2011). In the Mstów area and in some springs of various types studied by Czachorowski (1990) only the typically crenophilic species Drusus trifidus was found. However, the fact that all larval stages are found in a short springbrook $(30 \mathrm{~m})$ proves that the whole development cycle occurs there.

The springs, springbrooks and a pond studied here are concentrated in a small area, and therefore even a minor environmental disaster may result in the disappearance of communities living in these habitats. This concerns mainly non-insect fauna, particularly $G i$ anus aquedulcis, known in Poland from this region only (Dumnicka 2009).

\section{References}

Barquin J. \& Death R.G. 2004. Patterns of invertebrate diversity in streams and freshwater springs in Northern Spain. Arch. Hydrobiol. 161: 329-349. DOI: 10.1127/00039136/2004/0161-0329

Barquin J. \& Death R.G. 2011. Downstream changes in spring-fed stream invertebrate communities: the effect of increased temperature range? J. Limnol. 70: 134-146. DOI:10.4081/jlimnol. 2011.s1.134

Biesiadka E., Cichocka M. \& Warzecha B. 1990. Water mites (Hydracarina) of the springs in the Kraków - Częstochowa and Miechów Uplands. Acta Hydrobiol. 32: 171-186.

Botosaneanu L. (ed.) 1998. Studies in Crenobiology. The Biology of Springs and Springbrooks. Backhuys Publishers, Leiden, 261 pp. ISBN: 978-9073348042

Cantonati M., Gerecke R. \& Bertuzzi E. 2006. Springs of the Alps - sensitive ecosystems to environmental change: from biodiversity assessments to long-term studies. Hydrobiologia 562: 59-96. DOI: $10.1007 / \mathrm{s} 10750-005-1806-9$

Chełmicki W. (ed.) 2001. Żródła Wyżyny Krakowsko-Wieluńskiej i Miechowskiej. Zmiany w latach 1973-2000. UJ, Kraków, 127 pp. ISBN: 83-88424-07-6

Czachorowski S. 1990. Caddisflies (Trichoptera) of the springs of the Kraków - Częstochowa and Miechów Uplands (Poland). Acta Hydrobiol. 32: 391-405.

Dumnicka E. 2006. Composition and abundance of oligochaetes (Annelida: Oligochaeta) in springs of Kraków-Częstochowa Upland (Southern Poland): effect of spring encasing and environmental factors. Pol. J. Ecol. 54 (2): 231-242.

Dumnicka E. 2009. New for Poland Tubificidae (Oligochaeta) species from karstic springs. Pol. J. Ecol. 57 (2): 395-401.

Dumnicka E., Galas J. \& Koperski P. 2007. Benthic invertebrates in karst springs: does substratum or location define communities? Int. Rev. Hydrobiol. 92: 452-464. DOI: 10.1002/iroh.200610991

Dynowska I. 1983. Żródła Wyżyny Krakowsko-Wieluńskiej i Miechowskiej. Studia Ośrodka Dokumentacji Fizjograficznej PAN 11, Zakład Narodowy im. Ossolińskich, Kraków, 244 pp. ISSN: 0137-2939

Erman N.A. \& Erman D.C. 1995. Spring permanence, Trichoptera species richness, and the role of drought. J. Kansas Entomol. Soc. 68 (2), Suppl.: 50-64. WOS:A1995RQ68100 005

Fisher S.G. \& Likens G.E. 1973. Energy flow in Bear Brook, New Hampshire: an integrative approach to stream ecosystem metabolism. Ecological Monographs 43 (4): 421-439.

Galas J. 2005. Human impact on physical and chemical properties of springs from Cracow-Częstochowa Upland (Southern Poland). Pol. J. Ecol. 53: 329-341.

Glazier D.S. 1991. The fauna of North American temperate cold springs: patterns an hypotheses. Freshwater Biol. 26: 527542. DOI: $10.1111 /$ j.1365-2427.1991.tb01417.x

Koperski P., Dumnicka E. \& Galas J. 2011. Abiotic parameters determining fauna composition in karstic springs. Pol. J. Ecol. 59 (1): 153-163.

Lindegaard C., Brodersen K.P., Wiberg-Larsen P. \& Skriver J. 1998. Multivariate analyses of macrofaunal communities in Danish springs and springbrooks, pp. 201-219. In: Botosaneanu L. (ed.), Studies in Crenobiology. The Biology of Springs and Springbrooks, Backhuys Publishers, Leiden, 261 pp. ISBN: 978-9073348042

Mc Cabe D.J. 1998. Biological communities in springbrooks, pp. 221-228. In: Botosaneanu L. (ed.), Studies in Crenobiology. The Biology of Springs and Springbrooks, Backhuys Publishers, Leiden, 261 pp. ISBN: 978-9073348042

Mc Cabe D.J. \& Sykora J.L. 2000. Community structure of caddisflies along a temperate springbrook. Arch. Hydrobiol. 148 (2): 263-282

Meffe G.K. \& Marsh P.C. 1983. Distribution of aquatic macroinvertebrates in three Sonoran Desert springbrooks. J. Arid Environ. 6 (4): 363-371.

Pazdro Z. \& Kozerski B. 1990. Hydrogeologia ogólna. Wyd. Geol. Warszawa, 623 pp. ISBN: 83-220-0357-9

Resh V.H. 1983. Spatial differences in the distribution of benthic macroinvertebrates along a springbrook. Aquatic Insects 5 (4): 193-200. DOI: 10.1080/01650428309361145

Smith H. 2002. The hydro-ecology of limestone springs in the Wye Valley, Derbyshire. Water Environ. J. 16 (4): 253-259. DOI: $10.1111 / \mathrm{j} .1747-6593.2002 . t b 00412 . \mathrm{x}$

Smith H., Wood P.J. \& Gunn J. 2003. The influence of habitat structure and flow permanence on invertebrate communities in karst spring system. Hydrobiologia 510 (1-3): 53-66. DOI: 10.1023/B:HYDR.0000008501.55798.20

Uzunov J., Košel V. \& Sládeček V. 1988. Indicator value of freshwater Oligochaeta. Acta Hydrochim. Hydrobiol. 16 (2): 173186. DOI: $10.1002 /$ aheh. 19880160207

Van der Kamp G. 1995. The hydrogeology of springs in relation to the biodiversity of spring fauna: A review. J. Kansas Entomol. Soc. 68 (2), Suppl.: 4-17.

Von Fumetti S., Nagel P. \& Baltes B. 2007. Where a spring-head becomes a springbrooks - a regional zonation of springs. Arch. Hydrobiol./ Fundament. Appl. Limnol. 169 (1): 37-48. DOI: 10.1127/1863-9135/2007/0169-0037

Received January 27, 2012 Accepted October 16, 2012 